\title{
Oil and Revolutionary Governments: Fuel for International Conflict
}

\author{
Jeff D. Colgan
}

\begin{abstract}
Oil-exporting states, or petrostates, engage in militarized interstate disputes (MIDs) at a much higher rate on average than nonpetrostates. Why is this so? Further, what explains the variation among the petrostates in adopting aggressive foreign policies and engaging in MIDs on that basis? This article develops a theory that proposes that revolutionary petrostates have a higher propensity to launch MIDs than comparable nonpetrostates. This theory is tested with statistical analysis using a new quantitative data set that identifies revolutionary governments in the period 19452001. The results show that petro-revolutionary governments constitute a special threat to international peace and security. This evidence of resource-backed aggression challenges the conventional view of petrostates as the targets of international competition for resources.
\end{abstract}

The vital role of oil in the modern global economy makes the geopolitics of energy one of the most important issues in contemporary international affairs. ${ }^{1}$ Unfortunately, petrostates - states in which revenues from net oil exports constitute at least 10 percent of gross domestic product (GDP) — are among the most violent states in the world. Petrostates show a remarkable propensity for militarized interstate disputes (MIDs): on average, they engage in MIDs at a rate more than 50 percent higher than nonpetrostates. ${ }^{2}$ What explains this correlation between oil and international conflict?

Some observers argue that petrostates are more attractive as targets of international conflict due to their oil resources. However, this explanation is based on

Thanks are owed to Robert Keohane, Thomas Christensen, Christina Davis, and Jennifer Widner, as well as to Marc Busch, Sarah Bush, Sarah Bermeo, Joanne Gowa, Jessica Green, Michael McKoy, Michael Miller, Ed Rhodes, Jordan Tama, and participants of the 2008 IPES, 2009 ISA, 2009 MPSA, and 2009 APSA conferences, as well as the Princeton graduate IR seminar and the Georgetown faculty trade group for comments on earlier drafts of this article. Financial support from the Bradley Foundation, the Niehaus Center for Global Governance, the Woodrow Wilson School, and the Social Sciences and Humanities Research Council of Canada is gratefully acknowledged.

1. This article provides highlights from a large research project, the full findings of which are to be presented in a forthcoming book on the subject of oil and war.

2. For petrostates, the rate is an average of 0.69 MID per year, compared to 0.44 per year for nonpetrostates. The figures given here are based on the Correlates of War (COW) data set (1945-2001) and the author's analysis. See Table 1. 
the idea that petrostates are primarily on the defensive in international conflicts, and this premise is not supported by the evidence. As this article shows, the link between oil and conflict is driven primarily by petrostates that are aggressive in international conflicts. Examples of such actions are not hard to find: Iraq's invasion of Iran and Kuwait; Libya's repeated incursions into Chad in the 1970s and 1980s; and Venezuela's mobilization for war against Colombia in 2008. This means that the standard explanation of the link between oil and international conflict is at best incomplete. It also means that the primary object of this investigation is a state's propensity to launch MIDs as an aggressor.

Revolutions and revolutionary governments are the key to understanding the link between oil and international conflict. Some scholars hypothesize revolutionary states to be disproportionately aggressive and conflict-prone members of the international system. Oil is theorized to have two general effects on a state's propensity for international conflict. One effect is conflict-enhancing (by reducing the leader's risk of domestic punishment for foreign policy adventurism and increasing the state's military capacity) and the other is conflict-reducing (by increasing the economic incentives for peaceful international trade and stability in the global oil export market). Oil has a special role to play in interacting and amplifying the effect of domestic revolutions on international conflict. When the state leader has aggressive, risk-acceptant preferences, as is likely under a revolutionary government, the political autonomy provided by oil makes it more likely that the leader will decide to launch an international conflict. Thus petro-revolutionary states are more likely to engage in international conflict than comparable nonpetrostates, even though on its own (in the absence of a revolutionary government), oil tends to have little or no impact.

This final point bears emphasis: the argument that states simply fight over the oil does not explain, at least not fully, the relationship between oil and conflict. Indeed, the relationship cannot be properly understood theoretically without reference to the domestic political dynamics of petrostates, especially those with revolutionary governments. Understanding how oil income supports resource-backed aggression is thus critical for an accurate theoretical understanding of international conflict. This analysis also contributes to the growing literature on the relationship between international trade and conflict.

This article is structured as follows. The first section offers a brief critique of the existing literature before the theory and hypotheses are developed in the second section. The third section outlines the methodology, in which the crucial concept of revolutionary government is defined and operationalized. The following section presents the empirical results, which are quite striking and show strong support for the theory: petro-revolutionary states are more than three times as likely to launch a militarized interstate dispute as other states. This section also includes a brief investigation of the role of non-oil natural resources in international conflict. The last section addresses the possibility that oil income is involved in the emergence of revolutionary governments; the evidence suggests that this is not the case. 


\section{Literature}

Although the importance of oil to modern geopolitics and international political economy can hardly be overstated, it is curiously understudied by scholars of international relations. The history of the last half-century is punctuated by international conflicts involving petrostates such as Iraq, Iran, and Libya. What explains the correlation between oil and international conflict?

The scholarly work on the topic of oil and conflict can be divided according to three different concepts of "resource war" that are often conflated in the literature: resource conflict, which describes violent intrastate conflicts that are caused or exacerbated by resource abundance or environmental scarcity; resource competition, which describes international conflicts based on the pursuit of scarce resources; and resource-backed aggression, which describes international conflicts initiated by states with heavy resource-export incomes. The latter two categories are most important for this investigation, which focuses solely on international conflicts. ${ }^{3}$

Much of the literature on resource competition was first developed in the 1980s and 1990s, following the oil price shocks of the 1970s. Scholars argued that increasing global demand for oil would make war over the control of major oil-exporting regions likely. ${ }^{4}$ Russett suggested just this kind of conflict when he asked in the title of a 1981 article, "Security and the Resources Scramble: Will 1984 Be Like 1914 ?" 5 Yet the answer to his question was no. In the postwar era, international markets, rather than war between states, have largely managed competition over resources. ${ }^{6}$ Still, some scholars maintain that it is only a matter of time before major international wars erupt on the basis of competition for oil. ${ }^{7}$

While the idea of resource competition has some plausibility, most arguments that support it are flawed empirically by selecting on the dependent variable. That is, the case for resource competition is typically supported by reference to a set of wars in regions where there was some degree of oil production. Yet the identification of a few examples where war and oil production were coincident does not prove a causal relationship; wars happen whether oil is present or not. As skeptics have pointed out, little systematic evidence has been presented in support of this claim. Indeed, one prominent scholar argues that most such arguments are "bunk." Moreover, the claim that oil competition causes international war must be reconciled with the history of such major oil-exporters as Saudi Arabia, Indonesia, or Nigeria, which have had relatively peaceful international interactions over the past half-century (setting aside their domestic violence). In short, more systematic test-

3. For more on resources and civil war, see Collier and Hoeffler 2004; Fearon and Laitin 2003; Ross 2004 and 2006; and Smith 2004.

4. See Westing 1986; Homer-Dixon 1991; and Klare 2002 and 2004.

5. Russett 1981.

6. One notable exception is the Iraqi invasion of Kuwait in 1990.

7. Klare 2004 and 2008

8. Victor 2007. 
ing and evidence is needed to show if and how oil wealth creates incentives for resource competition.

Few scholars have considered the role of oil income in exacerbating international conflict by creating resource-backed aggression. On this view of the resource curse, possession of large natural resources can be converted into military and political assets in support of aggressive foreign policy. In contrast to the idea of resource competition, this view suggests that the petrostates are likely to be aggressors. ${ }^{9}$ The theoretical basis for resource-backed aggression, however, is still far from clear. Some have argued that such aggression is due to the military expenditures made possible by oil income. Klare argues that the possession of advanced military weaponry "inevitably fueled the expansionist impulses of certain Gulf leaders." 10 However, clearly not all petrostates are aggressive in their foreign policy. Kuwait has a population roughly equal to Libya's, with at least as much oil and military hardware, yet historically it has behaved far less aggressively than Libya. The theory needs to specify the conditions under which oil is used as an instrument of military aggression.

The role petrostates most frequently play in international conflicts is significant because it offers insight on the relative importance of resource competition, in which petrostates are attacked, and resource-backed aggression, in which petrostates aggressively launch conflicts. The Correlates of War (COW) database provides information on militarized interstate disputes, which can be divided into two categories: Aggressor-MIDs and Defender-MIDs. ${ }^{11}$

Table 1 shows the overall rates of militarized dispute onsets, divided into Aggressor- and Defender-MIDs depending on the role that the state played. As the table indicates, petrostates engage in Aggressor-MIDs at a rate 94 percent higher than that of nonpetrostates; for Defender-MIDs, the rate is 30 percent higher. Thus petrostates have a higher rate of both Aggressor- and Defender-MIDs than nonpetrostates, but the former is far more important in driving the overall rate. On reflection, these results are perhaps not surprising: they are consistent with the aggressive behavior of Iraq, Libya, and other petrostates. Thus the evidence suggests that in general, resource-backed aggression rather than resource competition is the principal driver of the correlation between petrostates and international con-

9. The terms "aggressor," "attacker," "initiator," and "revisionist" are used here interchangeably, as are "targets" and "defenders." The terms indicate which state seeks to revise the status quo by force. This is distinct from the state that makes the first military move (for example, fired the first bullet); on this point, see note 11 below.

10. Klare 2002, 52.

11. This is done using the COW coding of whether or not the state was acting as a "revisionist" party in the dispute- that is, a state that seeks to revise the status quo by force. Thus if the state is coded as revisionist, it is considered to be an attacker, and thus the incident is an Aggressor-MID for that state; otherwise, the state is treated as a defender, and the incident is a Defender-MID. This is arguably a better measure for this purpose than one focused on which side initiated the first military move (for example, fired the first bullet). COW database available at $\langle$ http://www.correlatesofwar.org $\rangle$, accessed 22 June 2010. 
flict. Consequently, the primary object of this investigation is a state's propensity to launch MIDs as an aggressor. This focus helps to explain the largest part of the relationship between oil and international conflict.

TABLE 1. MIDs, Aggressor-MIDs, and Defender-MIDs by state type, 1945-2001

\begin{tabular}{lccc}
\hline & MID onset & $\begin{array}{c}\text { Aggressor-MID } \\
\text { onset }\end{array}$ & $\begin{array}{c}\text { Defender-MID } \\
\text { onset }\end{array}$ \\
\hline $\begin{array}{l}\text { Nonpetrostate } \\
\text { Petrostate }\end{array}$ & 0.440 & 0.180 & 0.261 \\
Petrostate as \% of nonpetrostate & 0.688 & 0.350 & 0.338 \\
& $156 \%$ & $194 \%$ & $130 \%$ \\
\hline
\end{tabular}

Notes: Count of MID onsets per state-year, average.

Source: COW MIDs data set v3.02, 1945-2001. All differences between petrostates and nonpetrostates are statistically significant.

In seeking to understand the propensity of petrostates to engage in AggressorMIDs, it is helpful to consider the factors that are already believed to shape statelevel preferences. Two factors stand out from the existing literature: the role of democracy, and the impact of domestic revolutions. The democratic peace literature suggests that democratic states do not go to war with each other, and since most petrostates are not democracies, the absence of democratic peace might be a contributing factor to the elevated conflict observed among petrostates. Yet there is considerable variation within the group of petrostates that cannot be explained by the democratic peace, as autocracy is (almost) a constant within this group. By contrast, the role of domestic revolutions in generating international conflict could explain both the elevated propensity for Aggressor-MIDs of petrostates, and the variation among the petrostates.

\section{Theory and Hypotheses}

The central argument of this article is that revolutions and revolutionary governments are the key to understanding the link between oil and international conflict. Revolutionary states are hypothesized to be disproportionately aggressive and conflict-prone members of the international system. Oil tends to have two effects: one that is conflict-enhancing and one that is conflict-reducing. When a revolutionary government comes to power in a petrostate, however, the conflict-enhancing effects of oil tend to outweigh the conflict-reducing effects. Consequently, the causal effect of oil on international conflict depends on the political conditions within the petrostate. The puzzle of why petrostates are so prone to engage in international conflicts can be explained largely by revolutionary petrostates. 
A revolutionary government is one that transforms the existing social, political, and economic relationships of the state by overthrowing or rejecting the principal existing institutions of society. ${ }^{12}$ A petrostate is a state in which the oil sector has a dominant role in the national economy (at least 10 percent of GDP). Details about the empirical operationalization of both terms are given below. This section first focuses on the effects of revolutionary governments, then on oil, and then on the interaction between the two.

\section{Revolution and State Conflict}

Revolutionary governments are more likely to be risk-acceptant and demanding than nonrevolutionary governments, in the sense that they have a greater desire to revise the status quo internationally (as well as domestically). This is principally explained by two causal mechanisms: selection of aggressive leadership and the removal of domestic political and institutional constraints.

Revolutionary states are hypothesized to select leaders who have stronger preferences for international conflict than nonrevolutionary leaders for two reasons. First, revolutionary leaders are likely to have greater risk acceptance for achieving their desired political outcomes than nonrevolutionary leaders, on average, because one does not become a successful revolutionary leader without a significant tolerance for risk. By dint of their rise to power, revolutionary leaders also become habituated to resolving political conflict by force (that is, perceiving the costs of violent conflict as low). ${ }^{13}$ These characteristics are likely to continue once they are in office because personal tendencies are persistent over time and preferred strategies are reinforced by habituation. Second, revolutionary leaders are likely to be particularly good at organizing and mobilizing their populations for campaigns of mass violence, a skill that was required for them to be successful in the domestic revolutionary struggle. ${ }^{14}$ These organizational skills, and the structure and procedures already in place as a result of the revolutionary mobilization, provide these leaders with a ready military resource, namely, a population mobilized to fight. This is not to argue that there is a single "revolutionary personality" or psychology that such leaders always have, but rather that the political dynamics of revolutions select certain leadership characteristics more frequently than a nonrevolutionary process.

The second reason revolutionary governments are more likely to initiate conflict is due to the removal of domestic constraints on the executive. Institutional weakness occurs in the revolutionary process as the domestic political landscape

12. This is similar to, but distinct from, the definitions provided by Walt 1996; Huntington 1968; and others. Some authors consider "true" revolutions to be exceedingly rare; the definition used here is intentionally somewhat broad. Note that a revolutionary state is simply a state that has a revolutionary government in power.

13. Gurr 1988.

14. Skocpol 1988. 
is overturned and replaced by a new order. Precisely because revolutionary leaders direct this process, they are likely to actively undermine institutional constraints on the executive. This means that leaders have more scope to pursue their preferences and eliminate or discount dissent from other members of the political elite. If a leader's preferences are aggressive and risk-acceptant, as they are likely to be on average, then the state is more likely to follow the leader into war when there are few domestic constraints upon the state's leadership. ${ }^{15}$

Every revolution has its particular political dynamics, and not all of them will produce leaders and governments with the characteristics just described. Nonetheless, on average there is a tendency in revolutionary politics to select radical and risk-acceptant leaders, and to overturn domestic constraints in favor of a strong executive that can pursue revolutionary goals. These tendencies follow from the incentives generated by revolutionary movements, even if the actual outcomes are idiosyncratic to each particular revolution.

In sum, this theoretical discussion leads to the first hypothesis:

H1: States led by revolutionary governments are more likely to launch militarized interstate disputes than comparable states with nonrevolutionary governments.

This hypothesis should be situated in the broader theoretical context. In his seminal book Revolution and War, Walt theorizes the relationship between revolution and international conflict as arising from changes in the "balance of threat" between states. He emphasizes causal mechanisms based on international systemic factors more than those based on domestic factors. By contrast, the present work focuses on domestic factors and attempts to provide a richer and more precise set of causal mechanisms arising from domestic politics. However, nothing in the theory presented here is inconsistent with the idea that international systemic factors also play a role in the link between revolution and war. The key point, in terms of how revolution is linked to oil and international conflict, is that domestic politics is an essential cause of revolutionary states' elevated propensity for international conflict. On this point, Walt clearly agrees. ${ }^{16}$ Other scholars are perhaps even more comfortable with the notion that revolutionary states are aggressive, and that this is an outgrowth of their unit-level characteristics. ${ }^{17}$ The existing literature also suggests that revolutionary governments are more likely to be the targets of inter-

15. Of course, this lack of constraints does not last forever; as new institutions are built to replace the old ones, and political behavior becomes regularized (even in regimes that espouse permanent "revolutions"), political and institutional constraints on the executive may begin to re-emerge. This revolutionary life-cycle, in which the political dynamics and institutional constraints in a revolutionary state are not constant over time, can and should be explored in future work.

16. Walt dismisses simplistic arguments based on the aggressiveness of revolutionary states (1996, $10-12$ ), but he clearly argues that revolutionary states are indeed more likely to be aggressive than nonrevolutionary ones (ibid., see especially, 38, 65-70, 223-25).

17. See Gurr 1988; Skocpol 1988; Maoz 1996; Snyder 1999; and Enterline 1998. 
national conflict than nonrevolutionary governments, but this is not central to the dependent variable under analysis here. ${ }^{18}$

\section{Oil and State Conflict}

Oil income is theorized to have two effects on petrostates' foreign policy behavior, with opposite implications for international conflict. On one hand, oil lowers the risks for the leader of domestic punishment for aggressive foreign policy and provides resources that can be used to increase the state's military capabilities. On the other hand, oil increases the economic incentives to maintain peace and stable trade relationships with the international community.

The first mechanism increases the probability of international conflict. One of the special properties of oil income is that the central state can easily control and monopolize this income. This gives the leader an independent source of financial resources, which in turn generates political resources. ${ }^{19}$ The leader of a petrostate has a greater degree of policy autonomy than a nonpetrostate leader, on average, because of the greater ability to redistribute income to buy political support. ${ }^{20}$ Political autonomy represents the extent to which the leader is able to take decisions that differ from the preferences of the domestic audience. Consequently, the leader of a petrostate faces a lower risk of being removed from office or otherwise punished for potentially unpopular foreign policy adventurism. ${ }^{21}$

The lower risk of leader punishment due to international conflict is evident in a number of petrostates. Saddam Hussein led Iraq into a costly and bloody war with Iran that ended after eight years in little gain for either side; yet he was not removed from office. Even after he launched another unsuccessful war against Kuwait in 1990, he continued to maintain power for years until he was finally removed, not by domestic opposition, but by an external invading force. Iran's Ayatollah Khomeini also faced significant opposition to his policy of continued warfare in

18. Briefly, three reasons are given: first, neighboring states fear that the revolutionary process will spill over; second, neighboring states see revolutionary states as temporarily weakened, creating a window of opportunity for predation; third, information asymmetries and heightened uncertainty can increase the potential for conflict. For more details, see Maoz 1989 and 1996; Walt 1996; and Kydd 2000.

19. As Dahl (1961) observed more than a generation ago, the question of who governs depends greatly on who has access to resources; the individual's resources tends to be proportional to his political influence, or at least the potential for it.

20. The political effects of oil have been usefully explored by a number of scholars including Karl 1997; Ross 2001; Dunning 2008; and Morrison 2009.

21. The argument focuses on the level of domestic political risk that a leader faces for seeking to alter the international status quo (that is, for launching a questionable international conflict, especially if it results in failure), but some leaders face the opposite risk: that is, being too conflict-averse and failing to act on the aggressive preferences of the domestic audience. It is true that both of these risks can exist, but the argument of this article assumes that the political risks associated with trying to alter the status quo (for example, by launching a war) are greater than the risks associated with maintaining the status quo (for example, by keeping the peace). This assumption is based on the idea that a leader will almost certainly face political risks and criticism after a defeat in a significant militarized conflict, whereas a leader's risk for maintaining peace tends to be less focused and more easily deflected. 
the Iran-Iraq war, especially after Iraq offered to settle the dispute in 1982, but he was able to isolate his domestic enemies and continue the war for another six years, at huge cost to his country. Libya's Muammar Qadhafi also faced significant domestic opposition to his foreign policy aggression, which included an intermittent war with Chad, the support of at least thirty foreign insurgencies around the world, and several major acts of international terrorism. Despite the domestic opposition to his adventurism, Qadhafi has been able to maintain power for four decades. Indeed, in contrast to nonpetrostates, there is no evidence that a leader has ever lost power in a petrostate due to his foreign policy adventurism. The theoretical hypothesis being made here suggests that these facts are explained, in part, by the greater political autonomy afforded to the leader by the state's oil resources.

Oil also increases a state's military capability. Again, the nature of oil income plays a crucial role: it provides the state with a larger and more fungible pool of funding for military expenditures than it would otherwise have. Empirically, this means that petrostate spending on military expenditure, as a percentage of GDP, is considerably higher than it is in nonpetrostates. This is likely to be especially evident in periods of high oil prices, when petrostates frequently engage in spending sprees on military equipment and personnel. The centralized resources of a petrostate make it more capable of engaging in militarized conflict should it choose to do so, relative to a comparable nonpetrostate.

On the other hand, oil income also generates significant incentives to avoid international conflict and maintain peace and stability. Oil-exporting petrostates face unusually strong economic incentives to maintain stable trade connections with the international community. ${ }^{22}$ In the short-term, there are direct financial opportunity costs to interrupting the trade of oil. For example, despite his fiery rhetoric against the United States, Venezuela's President Hugo Chavez has not followed through on his threats to cut off oil exports to the United States, most likely because he realizes how valuable those exports are to his government. Another potential cost is the loss of assets invested overseas that are frozen or seized after the outbreak of conflict, such as when the United States froze Iranian assets during the embassy hostage crisis in 1980. Given the nature of petrostates' economies, they are likely to have a sizeable amount of overseas assets (more recently in the form of sovereign wealth funds). There are also long-term costs to conflict for petrostates: oil-consuming states respond to price volatility with source diversification and alternative fuel investment. ${ }^{23}$ For these reasons, petrostates face significant incentives

22. Oil also provides the petrostate with a substitute tool with which to pursue its foreign policy objectives: using "check-book diplomacy" or funding foreign insurgents.

23. Oil must compete with other energy alternatives in the long run, and international conflict drives up the cost of oil relative to its competitors. This was evident in the change in the energy consumption profile of the United States and other Western states in the 1970s, when questions about the cost and reliability of oil supply were being raised: oil lost market share to other energy sources, and was essentially eliminated from use for electricity generation. At least for large exporters of oil, interruptions of 
to maintain international peace and stability, and to prevent the interruption of oil exports. $^{24}$

Oil income therefore creates opposing incentives for petrostate leaders considering the use of force to revise the status quo: it makes international conflict both more and less costly than for nonpetrostates. These opposing incentives tend to amplify the difference between revolutionary and nonrevolutionary governments.

\section{How Does Oil Income Interact with Revolutionary Governments?}

For states in which a revolutionary government has taken power, oil increases the state's propensity to launch international conflicts. One of the key effects of oil income is to increase the leader's political autonomy and reduce the leader's risk of being punished by domestic audiences for foreign policy decisions. For the reasons provided earlier, a revolutionary leader is likely to have risk-acceptant and aggressive preferences. The combination of aggressive preferences and the reduced risk of domestic punishment makes it especially likely that leaders will decide to launch an international conflict. In addition, when leaders have aggressive preferences, they are more likely to take advantage of the fiscal flexibility provided by oil income to purchase weapons and enhance the state's military capability. Consequently, the theory predicts that:

H2: The difference in a state's propensity to launch international conflict between revolutionary and nonrevolutionary governments will be greater in petrostates than in nonpetrostates.

In nonrevolutionary petrostates, the leader is more likely to have risk-averse, nonaggressive preferences than revolutionary leaders. Oil still provides political autonomy and increases the leader's ability to take risks on international conflict, but this ability raises the state's propensity for conflict far less than it would if the leader had risk-acceptant, aggressive preferences, as is typical in a revolutionary state. Indeed, this effect may be swamped by the conflict-reducing effect of oil.

These hypotheses can be tested using empirical evidence on militarized interstate disputes. Figure 1 portrays the empirical predictions resulting from $\mathrm{H} 1$ and H2. To clarify, the theory does not generate a specific hypothesis about the abso-

supply caused by international conflict raise the risk that consuming nations will permanently alter their consumption patterns away from oil.

24. The expectation that oil exports create incentives for petrostates to avoid international conflict touches on the larger issue of the general relationship between trade and conflict. The argument here is consistent with those scholars (see, for example, O'Neal and Russett 2001; Keohane and Nye 1977; and Gartzke 2007) who argue that trade has a pacifying effect, though this effect is disputed by some (Barbieri 2005). 
lute magnitude of petrostates' propensity for international conflict. Instead, it predicts that the difference between a revolutionary and nonrevolutionary state in terms of its propensity for launching conflict will be greater if the state is a petrostate. ${ }^{25}$ This expectation is tested quantitatively in the next section.

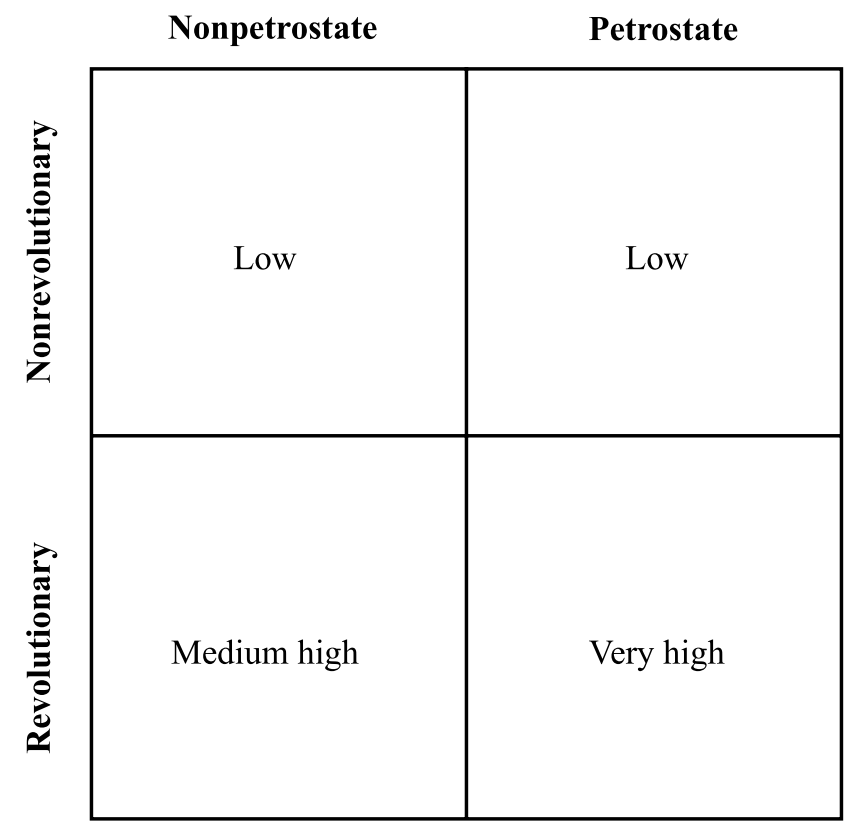

FIGURE 1. Emperical expectations for states' propensity to launch international conflict

\section{Monadic Theory and Dyadic Conflict}

The theory just presented is a monadic theory, in the sense that it focuses on the domestic politics of a single state to explain a particular phenomenon. Yet the phenomenon that the theory helps to explain is international conflict, which is dyadic and involves strategic interaction. Scholars of international relations emphasize the strategic nature of conflict, in which states' actions are guided by their anticipation of others' actions and the expected outcome. Some scholars argue that when power is balanced, no side believes it holds a clear advantage, and thus no side

25. Mathematically, if the conflict propensity of a nonrevolutionary nonpetrostate is NPNR; the propensity of a revolutionary nonpetrostate is NPR; the propensity of a nonrevolutionary petrostate is PNR; and the propensity of a revolutionary petrostate is PR; then PR-PNR > NPR-NPNR. 
wants to initiate a risky and costly conflict. ${ }^{26}$ Others argue that a clear imbalance of power solves the question of which side would win a war, and thus peace prevails because the weaker side rationally avoids a conflict. ${ }^{27}$ More recently, Fearon and others argue that the distribution of power is irrelevant if actors are strategic and rational, as they ought to be able to reach a bargain that reflects the balance of power and therefore avoid a costly conflict. ${ }^{28}$ How then does the theory of oil and revolution speak to the strategic and dyadic nature of international conflict?

This theory takes seriously the notion that states are continuously involved in a two-level game that involves the international actors (states), on one level, and the individuals and institutions within a state's domestic politics on a second level. ${ }^{29}$ For simplicity, the theory of oil and revolution focuses on the dynamics of only one state, but it should be understood that these theoretical effects also apply in the other state(s) involved in a potential international conflict. The domestic politics within each state influences the interactions between states in the international game. Domestic factors (for example, a recent revolution) can make a state more or less demanding at the international level by altering the perceived payoffs to victory and defeat, the risk tolerance, and the perceived costs of fighting. As the state becomes more demanding at the international level, the status quo is more likely to be perceived as unacceptable, and the perceived win set shrinks or disappears. (The win set is the range of outcomes that satisfies both sides without recourse to armed conflict.) In the absence of perfect information, a smaller win set makes it more difficult to reach a solution via bargaining, and thus raises the likelihood of conflict. Consequently, the probability of international conflict is increased when the domestic politics of one or both sides makes the state(s) more demanding. Indeed, the study of international security has moved increasingly toward investigation of the causes of war arising from domestic-level factors. ${ }^{30}$

The process by which the perceived win set shrinks can be further clarified. The theory here suggests that oil and revolutionary government interact to generate more aggressive preferences and risk tolerance, often causing the state to demand a change in the international status quo. Other states will have uncertainty about the changes in the petro-revolutionary state's preferences and risk tolerance, making it impossible for them to know how much the win set has changed, and thus how best to react strategically. For instance, outside observers might know that revolutionary leaders have aggressive preferences and less risk aversion toward conflict in general, but significant uncertainty will remain about a specific revolutionary leader's preferences and risk tolerance in a specific situation. This creates an information asymmetry because revolutionary leaders knows their own prefer-

26. See Morgenthau 2005; and Mearsheimer 1990.

27. See Blainey 1988; and Organski and Kugler 1980.

28. See Fearon 1994 and 1995; Powell 1999; and Filson and Werner 2004.

29. Putnam 1988.

30. See Bueno de Mesquita et al. 2003; Chiozza and Goemans 2004; Mansfield and Snyder 2005; Tomz 2007; and Gleditsch, Salehyan, and Schultz 2008. 
ences and risk tolerance with greater accuracy than the outside observer. Similarly, it might be known that, in general, oil revenues increase the domestic political autonomy of the leader, but an outside observer cannot perfectly evaluate a specific leader's political autonomy and its effects for the state's foreign policy. The combination of aggressive foreign policy and uncertainty create conditions in which conflict is likely.

Sensitivity for the distinction between monadic and dyadic theory is important in the empirical testing of the theory. This article uses both monadic and dyadic tests, each offering slightly different perspectives, as well as advantages and disadvantages.

\section{Methodology}

\section{Dependent Variable}

The theory developed in this study is tested using statistical analysis. The primary dependent variable is the onset of MIDs, with a special focus on whether the state's role in a dispute was as an aggressive (revisionist) power or a defensive (nonrevisionist) power. MIDs are a class of international events in which a state threatens, displays, or uses force against another state(s). While there is heterogeneity in these events, from full-fledged wars to relatively minor disputes, they provide considerable information about a state's interstate conflicts. These events have been coded in the COW data set, ${ }^{31}$ and the data are widely used by scholars for studying international peace and conflict. ${ }^{32}$ (All data including the COW data sets have their limitations, so the International Crisis Behavior data set was used as a robustness check; the results are broadly similar.) This analysis focuses on the onset of MIDs, since the factors leading to dispute onset are not necessarily the same as those that lead to dispute continuation or duration. The analysis begins by focusing on a monadic property - the state's propensity for an MID—and then moves to a dyadic analysis.

Operationally, the main dependent variable is AGGRESSOR-MIDS, which is a count of the MID onsets in each year in which the state has been coded as the revisionist (or aggressor) state. This follows from the fact that one of the major theoretical claims being tested is that revolutionary governments, especially petro-revolutionary governments, are aggressive rather than simply being the targets of disputes. ${ }^{33}$ Some variants of this dependent variable are also used, including MIDS (all MID onsets involving the state), and DEFENDER-MIDS (MID onsets in which the state is coded

31. COW data set, v3.02. Available at 〈http://www.correlatesofwar.org $\rangle$, accessed 22 June 2010.

32. See Bueno de Mesquita et al. 2003; Chiozza and Goemans 2004; Mansfield and Snyder 2005; Tomz 2007; and Gleditsch, Salehyan, and Schultz 2008.

33. The analysis uses the "revisionist" variable rather than the "side A" initiator, as the authors of the COW data set specifically warn against this latter practice (Jones, Bremer, and Singer 1996). Despite this warning, as a robustness check the "side A" indicator was used as an alternative to the principal dependent variable; the results did not materially change. 
as nonrevisionist). The time period of the analysis is 1945-2001, based on the availability of data.

\section{First Explanatory Variable: Revolutionary Government}

One problem that has plagued the research on revolution and war is that there is no widely accepted universe of cases of revolution or revolutionary governments. Indeed, variations on the universe of cases are almost as numerous as the number of scholars who have examined the question. ${ }^{34}$ This difficulty can lead to selection bias in the empirical testing of theoretical hypothesis, particularly if the analysis focuses on cases that are supportive of the theory. Avoiding this bias is facilitated by using a comprehensive domain of cases, subject to a well-specified identification procedure. Accordingly, a unique data set was constructed to operationalize the variable, REVOLUTIONARY GOVERNMENT. Each state-year is given a dichotomous $1 / 0$ coding, based on two principal criteria plus two additional filters. "Governments" and "leaders" are used interchangeably: for the purpose of this data set, a government is equivalent to the period of time that a leader was continuously in power (for example, four or eight years for a U.S. president). Each observation in the data set was coded independently at least twice, by different coders. ${ }^{35}$ Greater detail on all of the coding rules is given in the codebook. ${ }^{36}$

The first criterion for the coding is whether the leader came to power through use of armed force, widespread popular demonstrations, or similar uprising (henceforth called an "an irregular transition"). Two questions were used for this coding. First, has the individual leader used armed force against his or her state at any time prior to coming to office as an integral part of rising to national influence, and ultimately, state leadership? Second, were there mass demonstrations or uprisings, violent or nonviolent, which were instrumental in deciding the outcome of the transition? If the answer to either of those questions was yes, the transition was coded as irregular. This specification implies that the rise of a leader such as Adolph Hitler, who led an attempted (but failed) coup in Germany in the 1920s to rise to national influence and was subsequently elected to office in the 1930s, is considered as an irregular transition and thus potentially revolutionary. The term "used armed force" requires leadership in the act; an individual who is a relatively low-level functionary of a revolution or coup is not considered to have led it. It is possible for more than one leader to have "led" an irregular transition, but the leadership is restricted to its senior leaders. Thus both Vladimir Lenin and Joseph

34. Walt focuses his (1996) research on revolution and war on ten cases of "unambiguous" revolutions, though he suggests in later work that many other cases exist. Skocpol (1988) focuses on only the "great" revolutions, which appears to limit the universe of cases to fewer than ten. Snyder identifies twenty-four revolutions during the Cold War for his research (Snyder 1999).

35. I am grateful to Summer Lopez, Thomas Scherer, and Lamis Abdel-Aziz for their assistance in this effort.

36. Available from the author on request. 
Stalin can be considered to have had an "irregular transition" as leaders of the Russian Revolution, but not Nikita Khrushchev, even though the latter fought in the Red Army at a young age.

The second criterion is that once in power, the government must have implemented radical domestic changes for the purpose of transforming the organization of society, including its social, economic, and political institutions and practices. In all cases, the focus is on domestic policy, rather than foreign policy. Seven possible areas of change have been identified: the selection and power of the national executive; the structure of property ownership; the relationship between state and religion; the official political ideology; the official state name; the institutionalized status of ethnicity and gender; and the presence of a governing revolutionary council or committee. These areas were identified by studying the distinguishing characteristics of well-known revolutions. ${ }^{37}$ Dramatic changes in policy in at least three of the seven categories are required for the government's policy to be considered revolutionary. For example, the Iranian revolution in 1979 changed the relationship between state and religion (political dominance by clerics), the power and selection of the national executive (replacement of the monarchy by a clerical Supreme Leader), the status of women (inequality in inheritance law and segregation of the sexes), and the official name of the country (changed to the Islamic Republic of Iran), as well as many other changes. From a social science perspective, some of these categories are easier to objectively measure (for example, changes in the official name of the state), others are more directly connected to the substantive changes of interest (for example, a major change in the nature of the executive), but all of them provide information about the degree to which the state is transformed by the government. In all cases, changes are measured relative to the relevant prior government, rather than some external standard. Thus a change from monarchy to theocracy is equally revolutionary as a change from theocracy to monarchy.

Two types of governments are excluded from the revolutionary category even though they represent significant changes from the status quo. First, leaders who are installed by foreign powers after a major international war are not coded as revolutionary. States with foreign-installed leaders do not always have a free hand to control their state's policy, especially in the realm of foreign affairs; indeed, the behavior of such states has been shown to be considerably different from other states. ${ }^{38}$ Second, the founding government of a state is not coded as revolutionary, simply because it is often difficult or impossible to judge the degree to which a founding government changes the institutions relative to a "prior government" when no such government exists. ${ }^{39}$ When the two principal criteria are met, and neither of the exclusions applies, the state-year is coded as being a revolutionary govern-

37. The revolutions used to determine these categories were Iran (1979), Cuba (1959), China (1949), Ethiopia (1974), and Nicaragua (1979).

38. Lo, Hashimoto, and Reiter 2008.

39. Some colonies did have prior governments with similar territorial boundaries as the states that replaced them, but this is frequently not the case. 
ment. All state-years are also coded with a dichotomous variable called AMBIGUous to indicate borderline cases or cases where information was missing; this variable is used for robustness testing.

\section{Second Explanatory Variable: Petrostates}

The second key explanatory variable for this analysis is whether the state is a petrostate. For this analysis, the state's gross revenues from net oil exports must constitute at least 10 percent of annual GDP to be classified as a petrostate in a given year. There are thirty-three states that met this requirement for at least one year, as listed in appendix Table A1. Bahrain and Brunei are excluded due to their small size and lack of quality data, leaving thirty-one petrostates. This definition is used as the principal operationalization of the variables.

There are several alternative ways to operationalize the concept of "petrostate"; indeed, the best methodology has been the subject of some debate. ${ }^{40}$ Two methods to generate a continuous rather than dichotomous variable are to measure the revenue from petroleum exports as a percentage of GDP, or to measure the per-capita revenue associated with oil exports; each has its advantages and disadvantages. ${ }^{41}$ A third approach is to focus on total oil production instead of net oil exports; oil production as a percent of GDP was used to generate a dichotomous variable similar to the principal variable described earlier. A fourth measure can be generated by raising the threshold for the principal dichotomous variable to 20 percent, thereby excluding some of the more marginal cases. All of these other operationalizations are used as well as the principal variable to test the robustness of the empirical findings.

The third and most important explanatory variable is the interaction between petrostate and the revolutionary government, called PETRO REVOLUTION. This is also a dichotomous variable, which takes the value of 1 when both PETROSTATE and REVOLUTIONARY GOVERNMENT are equal to 1 ; otherwise it is 0 . The effect of introducing this variable into the regression is to isolate the specific political dynamics of revolutionary petrostates. The variable PETROSTATE thus focuses on the effect of oil politics in nonrevolutionary petrostates.

In the data, there are 804 state-years in which PETROSTATE has a value of 1; of these, PETRO REVOLUTION has a value of 1 in 125 state-years and 0 in the remainder. These observations are based on thirty-one petrostates over the time period 1945-2001. While there are five states that are classified as petrostates during the entire period under analysis, many states are classified as petrostates only for part of the time period under analysis, as oil is discovered or runs dry. This is an advan-

40. See Ross 2006.

41. Variants of these measures have also been used; see Ross 2001; and Ramsay 2006. Both of these approaches generate continuous measures, with the implicit assumption that a state that has a higher value is "more of a petrostate" than a state that has a lower value. It is not always clear that this assumption is warranted. 
tage, because it allows the variation over time within a state to be exploited for the purpose of analysis.

\section{Control Variables}

The regression controls for a set of other variables that could affect a state's propensity to engage in MIDs, and have been used by previous work in the literature. The analysis includes (logged) population size, (logged) GDP per capita, and the number of contiguous territorial borders with other states, as basic characteristics of a state's likelihood to engage in international conflict. These variables proxy for the degree to which the state is capable of waging war (population, GDP) and the geographical likelihood of contact and thus friction with its neighbors (borders). ${ }^{42}$

Democratic peace theory suggests that democracies may be less inclined to engage in revisionist MIDs than other kinds of governments. ${ }^{43}$ Modern theorists of the democratic peace argue that this tendency is strongest (and perhaps only present) in a dyad of two democracies. ${ }^{44}$ However, Kant's basic argument is that, in a republican regime, "those who would have to decide to undergo all the deprivations of war will very much hesitate to start such an evil game." 45 This suggests that democracies will be less likely to engage in war in general, regardless of their opponent. To address this possibility, the state's composite Polity IV score is included as a control variable. (As a robustness check, a dichotomous variable for democracy was also used. ${ }^{46}$ ) In the dyadic analysis, a dichotomous variable is used that is positive only when the dyad contains two democracies.

Major powers in the international system tend to take a much more active role than other kinds of states, even accounting for their large GDP and population sizes. This is addressed by introducing a dichotomous variable MAJOR POWER, following the COW data set's specification. A dummy variable was also included for the Cold War period (pre-1990), which may have altered the number of international disputes.

Some cultural dimensions are included. Huntington contends that religious and cultural factors shape the fault lines and disputes in the international system, and that Islamic countries in particular have "bloody borders" and "bloody innards" because they have cultural and demographic features that make them violenceprone. ${ }^{47}$ To account for this possible effect, the Muslim percentage of the population is used as a control variable. Each analysis also includes dummy variables for

42. See Lai and Slater 2006; Enterline 1998; and Gleditsch, Salehyan, and Schultz 2008.

43. O'Neal and Russett 2001.

44. See Bueno de Mesquita et al. 2003; and Maoz and Russett 1993.

45. Immanuel Kant, quoted in Levy 1988, 658.

46. For the dichotomous measure, the state is coded as a democracy if its composite Polity IV score is above +6 on the -10 to +10 scale; otherwise it is a nondemocracy.

47. Huntington 1996. 
each geographical region. Eight regions were used, similar to the World Bank's classification: North America, Latin America, Western Europe, Eurasia and Central Asia; Middle East and North Africa; South Asia; Sub-Saharan Africa; East Asia, and Pacific.

Finally, it has become standard practice in the literature to include a statistical control for temporal dependence, whereby some countries engage in multiple disputes over time: "war begets war." Following Beck, Katz, and Tucker, ${ }^{48}$ this analysis includes a natural spline function (with three knots) of the number of years that have elapsed since the country last experienced an MID. ${ }^{49}$ This spline function is included in all of the regression models, although the estimates of these parameters are not shown.

\section{Data}

Data on states' borders, population, and major power status come from the COW data set. Fearon and Laitin's data set $^{50}$ provides the GDP per capita data. The World Bank's World Development Indicators ${ }^{51}$ was used to provide GDP per capita data where they are missing from the Fearon and Laitin data. Data on states' religious makeup are based on the World Christian Database. ${ }^{52}$ The measure of government type is based on the Polity IV data set, as is the initial year as a polity. ${ }^{53}$ Data on oil revenues, prices, and export volumes are drawn from the BP Statistical Review of World Energy ${ }^{54}$ and the U.S. Energy Information Administration. ${ }^{55}$

Considerable effort went into addressing missing data and ensuring that the data set was as complete as possible. Reasonably high-quality data exist for most of the variables over this time period, such as population and state borders. However, other variables are more difficult. Only a single observation is available for the religious demographics of each country, but since this proportion is thought to change relatively slowly over time, this value is used for all years. The GDP per capita data from Fearon and Laitin are complete for 87 percent of the observations of interest but are missing for some of the key states such as Iraq. Consequently the World Bank data were used as a complement, bringing the total completion rate to 94 percent. The two data sources are generally consistent: for state-years where observations exist from both sources, the two data sets are correlated at the 0.96 level. With regard to oil income, the data for years prior to

48. Beck, Katz, and Tucker 1998.

49. See ibid.; and Mansfield and Snyder 2005.

50. Fearon and Laitin 2003.

51. World Bank, various years.

52. Available at $\langle$ http://www.worldchristiandatabase.org/wcd $\rangle$, accessed 22 June 2010.

53. This score is a proxy for the regime's "degree of democracy"; it ranges from -10 to 10 . See Marshall and Jaggers 2010.

54. Available at $\langle$ http://www.bp.com/statisticalreview $\rangle$, accessed 22 June 2010.

55. Available at $\langle\mathrm{http}: / / w w w . e i a . d o e . g o v\rangle$, accessed 22 June 2010. 
1965 are generally unavailable to the public. However, a special request was made for BP data for 1945-64 to complement the public reports, and these additional data allowed the analysis to be extended through the full time period.

\section{Empirical Results}

The data set contains 1,076 governments/leaders, containing data for 170 countries from 1945-2001, for a total of 6,407 state-years. ${ }^{56}$ As indicated earlier, each observation was coded twice, by different coders, and reconciled so as to improve the accuracy and concept validity of the data. Of this total set, eighty-four governments/leaders or about 7 percent are coded as revolutionary. ${ }^{57}$

The hypotheses are tested using a random-effects Poisson regression model adjusted for time-series panel data. Poisson regression is used because the dependent variable is a count variable, in which the variance is proportional to the mean; this follows the practice of previous work. ${ }^{58}$ The unit of analysis is the state-year. The base models use random effects for greater statistical efficiency in estimating the coefficients, but fixed effects models are also used in order to control for statespecific variables that do not vary over time. Table 2 shows the results of the analysis.

The results show significant support for the theory. States with revolutionary governments are associated with considerably more militarized interstate disputes than states without revolutionary governments, especially when they occur in petrostates. The dependent variable for all models in Table 2 is AGGRESSOR-MIDS. Model 1 is a basic model without the new data set on revolutionary governments, used as a baseline for comparability to other scholarly studies. Model 2 shows the changes when the new data are added; Model 3 is specified with panel fixed effects instead of random effects. ${ }^{59}$ As expected by $\mathrm{H} 1$, the coefficient for REVOLUTIONARY GOVERNMENT is positive and strongly significant, with confidence levels above 99 percent. This is true in all models, regardless of the specification used, suggesting a very strong relationship between revolutionary governments and MIDs.

56. Countries that do not have a Polity score are not coded. The "number of leaders" reported counts leaders who have come to office at two distinct times (with at least a year out of office) as two leaders; the number of unique leaders is slightly smaller.

57. Under a highly restrictive secondary definition, less than 1 percent of leaders are coded as unambiguously revolutionary. See the discussion under "Robustness Checks" for use of this definition.

58. Martin 1993. Negative binomial models were also used to test for possible overdispersion in the data, and the results were consistent. However, the Poisson models are preferred because they are more efficient (possibly much more efficient) in estimating the coefficients. See Wooldridge 2002, 657, 672-74, for more details.

59. Approximately 900 observations are dropped when switching from random-effects Models 2 and 4 to the fixed-effects Models 3 and 5. The dropped observations are ones where there is no withincountry variation on the dependent variable: that is, states that did not engage in any MIDs during the period of analysis. 
TABLE 2. International disputes by state type-monadic regression analysis

\begin{tabular}{|c|c|c|c|c|c|}
\hline $\begin{array}{l}\text { Dependent variable: } \\
\text { Aggressor-MIDs }\end{array}$ & $\begin{array}{c}\text { Model (1) } \\
\text { No revolution }\end{array}$ & $\begin{array}{c}\text { Model (2) } \\
\text { Base }\end{array}$ & $\begin{array}{l}\text { Model (3) } \\
\text { Base FE }\end{array}$ & $\begin{array}{l}\text { Model (4) } \\
\text { Petro base }\end{array}$ & $\begin{array}{l}\text { Model (5) } \\
\text { Petro FE }\end{array}$ \\
\hline REVOLUTIONARY & & $0.443 * *$ & $0.432 * *$ & $0.286^{* *}$ & $0.289 * *$ \\
\hline GOVERNMENT & & $(0.089)$ & $(0.094)$ & $(0.099)$ & $(0.104)$ \\
\hline PETROSTATE & & & & $\begin{array}{c}-0.433 * * \\
(0.158)\end{array}$ & $\begin{array}{r}-0.328 \\
(0.179)\end{array}$ \\
\hline PETRO REVOLUTION & & & & $\begin{array}{l}0.707 * * \\
(0.203)\end{array}$ & $\begin{array}{l}0.660 * * \\
(0.212)\end{array}$ \\
\hline GDP/CAP, $\log$ & $\begin{array}{r}-0.072 \\
(0.059)\end{array}$ & $\begin{array}{r}-0.022 \\
(0.060)\end{array}$ & $\begin{array}{c}0.059 \\
(0.075)\end{array}$ & $\begin{array}{c}-0.025 \\
(0.060)\end{array}$ & $\begin{array}{c}0.052 \\
(0.075)\end{array}$ \\
\hline POPULATION, $\log$ & $\begin{array}{l}0.237 * * \\
(0.067)\end{array}$ & $\begin{array}{l}0.236^{* *} \\
(0.067)\end{array}$ & $\begin{array}{r}-0.063 \\
(0.135)\end{array}$ & $\begin{array}{l}0.244 * * \\
(0.066)\end{array}$ & $\begin{array}{r}-0.070 \\
(0.137)\end{array}$ \\
\hline POLITY IV & $\begin{array}{c}-0.016^{*} \\
(0.007)\end{array}$ & $\begin{array}{r}-0.008 \\
(0.007)\end{array}$ & $\begin{array}{r}-0.004 \\
(0.008)\end{array}$ & $\begin{array}{r}-0.010 \\
(0.007)\end{array}$ & $\begin{array}{r}-0.006 \\
(0.008)\end{array}$ \\
\hline CONTIGUOUS BORDERS & $\begin{array}{l}0.141^{* *} * \\
(0.022)\end{array}$ & $\begin{array}{l}0.121 * * \\
(0.022)\end{array}$ & $\begin{array}{l}0.193 * * \\
(0.028)\end{array}$ & $\begin{array}{l}0.112 * * \\
(0.022)\end{array}$ & $\begin{array}{l}0.180 * * \\
(0.029)\end{array}$ \\
\hline COLDWAR & $\begin{array}{c}0.148 \\
(0.078)\end{array}$ & $\begin{array}{c}0.123 \\
(0.078)\end{array}$ & $\begin{array}{c}0.101 \\
(0.095)\end{array}$ & $\begin{array}{l}0.135^{* *} \\
(0.078)\end{array}$ & $\begin{array}{c}0.100 \\
(0.095)\end{array}$ \\
\hline MUSLIM, \%POPULATION & $\begin{array}{c}0.099 \\
(0.299)\end{array}$ & $\begin{array}{c}0.140 \\
(0.292)\end{array}$ & & $\begin{array}{c}0.182 \\
(0.287)\end{array}$ & \\
\hline MAJOR POWER & $\begin{array}{c}0.320 \\
(0.439)\end{array}$ & $\begin{array}{c}0.311 \\
(0.421)\end{array}$ & & $\begin{array}{c}0.330 \\
(0.413)\end{array}$ & \\
\hline Fixed effects & No & No & Yes & No & Yes \\
\hline$N$ & 6272 & 6244 & 5377 & 6244 & 5377 \\
\hline Log-likelihood & -2780 & -2755 & -2349 & -2747 & -2344 \\
\hline
\end{tabular}

Notes: All models use Poisson regression analysis for time-series panel data. Panel-adjusted standard errors are in parentheses. Regional dummies and a spline of peace years included but not shown. FE $=$ fixed effects. $* p<.05$; ** $p<.01$.

Models 4 and 5 introduce the second key variable, PETROSTATE, and the interaction variable PETRO REVOLUTION. As expected, the interaction variable PETRO REVOLUTION is positive and strongly significant, indicating that revolutionary governments in petrostates are even more warlike than revolutionary governments in nonpetrostates. This finding holds in Model 4, which replicates the specification structure of Model 2. The finding also holds in Model 5, which uses fixed effects to control for all state-specific variables that do not vary over time. The striking finding in Model 5 is that, even when the analysis focuses only on within-state variation over time, the interaction variable is found to be strongly associated with AGGRESSOR-MIDS. As expected by the theory, the coefficient for PETRO REVOLUTION is positive and strongly significant, again with confidence levels above 99 percent. Note also that this result is obtained even though the models include regional dummy variables, and thus controlling for variation in the amount of international conflict between regions (for example, controlling for the high levels of conflict within the Middle East). Thus there is considerable evidence to support the most important hypothesis, $\mathrm{H} 2$. 
Perhaps surprisingly, the coefficient on the variable PETROstate is negative, indicating an inverse correlation between nonrevolutionary petrostates and AGGRESSOR-MIDS. This finding is statistically significant in Model 4, but not significant in Model 5 once fixed effects are introduced. Thus these results are not conclusive, but they suggest that nonrevolutionary petrostates are no more likely to launch MIDs than comparable nonpetrostates, and possibly significantly less likely. This finding is striking because overall, the opposite trend holds: petrostates launch more MIDs on average than nonpetrostates. The implication is that the overall above-average rate of international disputes is driven almost entirely by the small subset of revolutionary petrostates, which are extremely aggressive; the rest of the nonpetrostates do not launch many MIDs. This finding provides further support for the claim that REVOLUTIONARY GOVERNMENT is an essential variable in explaining the behavior of petrostates and suggests that the conventional explanation for the relationship between oil and international conflict is not satisfactory.

The results also provide insight into the importance of the control variables in determining the conflict-proneness of a state. Consistent with earlier studies, the number of territorial borders is an important factor: the more contiguous neighbors a state has, the more opportunities it has for international disputes. Population size is associated with increased conflict-proneness cross-nationally, but this effect becomes statistically insignificant when state fixed-effects are added (Models 3 and 5). The Muslim percentage of the population, income per-capita, Cold War years (pre-1990), and the state's status as a major power are not associated with propensity for AGGRESSOR-MIDS in any of the models. Finally, the state's Polity score (from -10 to +10 ) is inversely associated with MIDs in Model 1, consistent with the hypothesis that democracies engage in fewer aggressive disputes. However, this relationship disappears (that is, is not statistically significant) in Models 2 to 5 , when the data on revolutionary governments are used. This latter result suggests that it may be worth investigating the extent to which revolutionary governments are related to the democratic peace thesis.

The magnitude of these statistical effects is worth considering. Figure 2 shows the effect of the variables PETROSTATE, REVOLUTIONARY GOVERNMENT, and PETRO REVOLUTION on the onset of aggressive MIDs for a typical state. In this comparison, a "typical state" is considered, in which population, GDP per capita, Polity score, Muslim percentage of the population, and the number of state borders are all set to the average of the data sample. ${ }^{60}$ The behavior of four types of this "typical state" is considered. The first type is a state that has no oil and is led by a nonrevolutionary government. As indicated by the bar on the left of Figure 2, such a

60. The model used for Figure 2 is Model 4. For the "typical state" being compared in Figure 2, the GDP per capita is $\$ 2,110$, the population is 8.3 million, Polity score is -0.6 , the state has 5.5 external borders, and Muslims make up 24 percent of the population. Other values, such as the geographic location of the state, the presence of the Cold War, and the state's status as a major power are not adjusted in this analysis, meaning that they vary according to the data within each category of Figure 2. 
state could be expected to aggressively engage in 0.11 MIDs per year, or about one every decade. The second type is a petrostate but is still led by a nonrevolutionary government; Figure 2 shows that such a state will aggressively engage in 0.09 MIDs per year. Thus as discussed previously, nonrevolutionary petrostates appear no more aggressive (and perhaps slightly less aggressive) than comparable nonpetrostates.

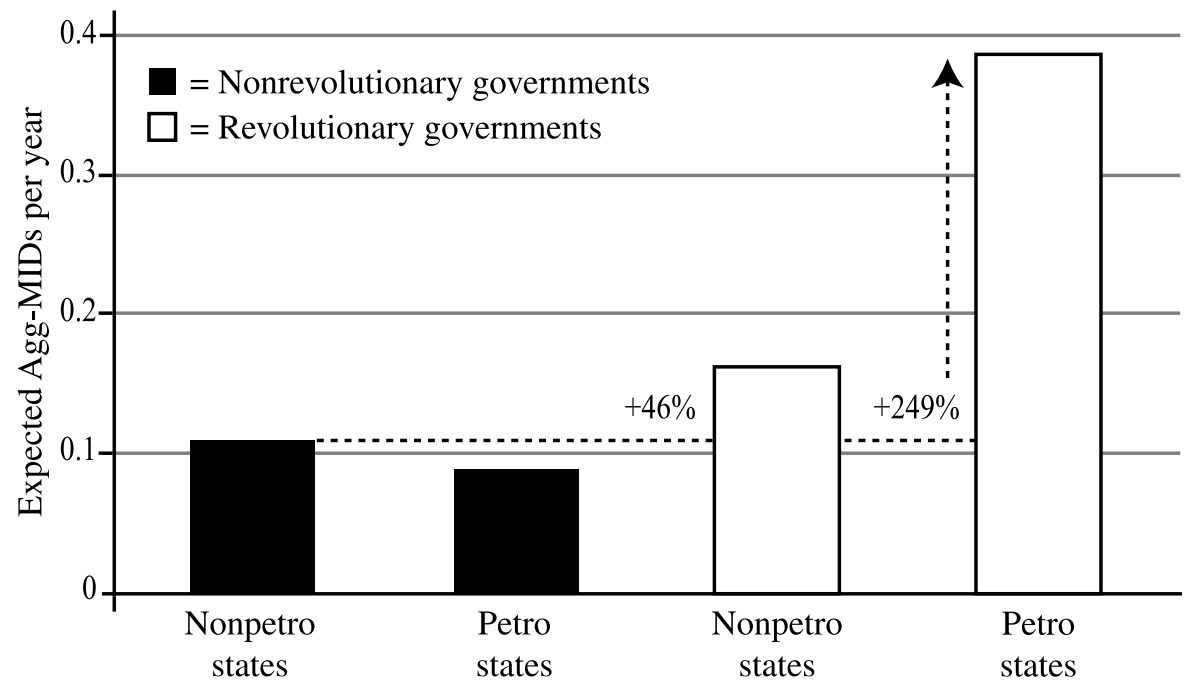

Notes: Error bars are not shown, but differences between the revolutionary and the nonrevolutionary governments are statistically significant, as are the differences between petro-revolutionaries and nonpetrostate revolutionaries.

FIGURE 2. Effect of the combination of oil and revolutionary governments on MIDs

The most important findings are shown in the two bars on the right-hand side of Figure 2. As expected, nonpetrostates with revolutionary governments aggressively engage in MIDs more than comparable states with nonrevolutionary governments; they do this at a rate of 0.16 per year, or 46 percent more per year than comparable states with nonrevolutionary governments. However, this difference pales in comparison to the effect of revolutionary governments in petrostates. Such states aggressively engage in MIDs at a rate of 0.39 per year, which is more than three times the rate of comparable nonpetrostates. ${ }^{61}$ As Figure 2 makes clear, the 
combination of a revolutionary government and an oil-exporting economy is a toxic mix for international peace and security.

These results suggest that the theory under investigation provides powerful insight into the behavior of petrostates. Indeed, when one moves past the quantitative results and considers a broader view of foreign policy behavior, the relationship between petro-revolutionaries and aggressive conflict becomes even more evident. This topic will be taken up in case studies in future work, but some examples can be highlighted here. In Iraq, Hussein seized power by force, revolutionized his country's domestic politics, and then used his country's oil income to centralize power and build a powerful military apparatus. Under his leadership, Iraq invaded both Iran (1980) and Kuwait (1990). Moreover, Iraq engaged in a number of lower-level militarized disputes with other states, including the Tanker Wars of the 1980s and violations of UN sanctions throughout the 1990s. In Libya, Qadhafi's revolutionary government aggressively engaged in four separate border wars with neighboring Chad, and a variety of militarized disputes with other countries such as Uganda, Sudan, and the United States. In addition, Qadhafi's government supported terrorists and insurgencies in at least thirty countries around the world, though this dimension of conflict activity is not captured in the MIDs data set. In Iran, the revolutionary government under Khomeini did not initiate the Iran-Iraq war, but it did decide to continue the war for many years after Hussein declared his willingness in 1982 to negotiate for peace. Further, Iran's continuing aggressiveness and pursuit of nuclear weapons in the twenty-first century can be attributed to the revolutionary hardcore members of its regime. In Venezuela, President Chavez's Bolivarian Revolution started when he came to power in 1999, largely too late to be captured in this data set (which ends in 2001). However, Chavez's multiple aggressive foreign policy actions, such as the Venezuela-Colombia military crisis in 2008, is consistent with the expectations of the theory being tested here.

One important petrostate that is not well-described by this theory is Russia. Russia's democratizing revolution under President Boris Yeltsin in 1990-91 did not generate an overly aggressive government. Russia did have a major militarized conflict with Chechnya and engaged in several MIDs during the 1990s, but on the whole was not markedly more aggressive than it had been as the USSR in previous years. However, this is understandable once the details of the revolution are understood. The hypothesized causal mechanisms, present in other cases of revolutionary governments, were largely absent in Russia during the 1990s. Rather than enabling the selection of a leader with warlike preferences and dismantling the institutional constraints on the executive, the revolutionary movement in Russia was toward democratization and decentralization of power. ${ }^{62}$ Moreover, many

62. President Yeltsin's regime was quite centralized and even autocratic by Western standards. However, in comparison to the Communist regime that preceded it, Yeltsin's regime was considerably more democratic. Moreover, the personalization of power was considerably less severe under Yeltsin than it has become in Vladimir Putin's regime. 
revolutionary governments (for example, Iran) are aggressive in part because the domestic regimes they overthrew were perceived as too conciliatory with the United States and other foreign powers, but in Russia, this was not the case. The Communist regime was a classic Cold War antagonist in the international system, and by opposing it, the revolutionary government was thus disposed to avoid international disputes rather than engage in them. It was not until the nationalistic backlash in the late 1990s, continued and inflamed by President Vladimir Putin, that Russia became more aggressive, leading to wars with both Chechnya and Georgia.

The theoretical hypotheses being tested in this study are thus strongly supported by the empirical evidence. It is worth noting that the number of petrostates in the world is relatively small, and so the number of petro-revolutionary governments under analysis is also small. This should make one cautious in reaching conclusions. Still, the data include 125 observations of petro-revolutionary stateyears. This analysis benefits from variation across countries as well as variation across time within countries, in which both the nature of the government and the state's oil income can change. The analysis of both cross-national and crosstemporal variation suggests that petro-revolutionary governments have a dramatically higher propensity for international conflict than comparable nonpetrostates.

\section{Dyadic Analysis}

Political scientists commonly model international conflict as a dyadic interaction. The theory being tested in this article is primarily about the unit-level characteristics of states, and therefore the monadic analysis used above is an appropriate initial testing method. However, the analysis can also be extended to dyadic tests. This sequential research design-first monadic, then dyadic-follows the practice of other scholars, such as Mansfield and Snyder. ${ }^{63}$ There are two principal benefits to the dyadic analysis. First, dyadic tests are able to control for dyadic attributes that might be omitted variables in a monadic analysis. Second, these tests allow the work presented in this study on oil and revolutionary states to be connected and compared easily to the large existing literature that is cast at the dyadic level of analysis.

This analysis uses data and methodology similar to that used by Gleditsch, Salehyan, and Schultz in their work linking civil wars and MIDs. ${ }^{64}$ Building on their model serves to increase the comparability between the results presented in this article and those already published. A logit regression model is used to conduct the analysis, with directed dyads as the unit of analysis. ${ }^{65}$ Consistent with much of

63. Mansfield and Snyder 2005.

64. Gleditsch, Salehyan, and Schultz 2008.

65. The monadic analysis used a Poisson regression because a significant number of observations have multiple MIDs in a given year. In the dyadic analysis, values greater than one are very rare, so a logit model is used instead. A rare events logit model was used as a robustness check; the results were consistent. 
the literature on international conflict, the data sample is restricted to politically relevant dyads: that is, only dyads in which the states are geographically contiguous or at least one of the states is a major power. The use of directed dyads allows the analysis to capture which state is the aggressor or revisionist party in the conflict.

Table 3 provides the results of the analysis, which are quite consistent with those from the monadic analysis. The table shows three models, each with a different dependent variable: Model 6 focuses on MIDs in which state A was the aggressor; Model 7 focuses on MIDs in which state A was the defender; and Model 8 uses all MID onsets. The results are most informative when the three models are interpreted together. Model 6 generates positive and significant coefficients for both REVOLUTIONARY GOVERNMENT and PETRO REVOLUTION for state A, as expected. Similarly in Model 7, these coefficients are significant for state B, which is typically the aggressor in these MIDs. In Model 8, the results are symmetric for states $\mathrm{A}$ and $\mathrm{B}$, and again show the positive and significant coefficients for REVOLUTIONARY GOVERNMENT and PETRO REVOLUTION as expected. Model 7 shows that revolutionary states are also more prone to DEFENDER-MIDS, as can be seen from the positive coefficient in the first row. (Somewhat curiously, the results in Model 6 for state B do not suggest that revolutionary states are more likely to be the targets of AGGRESSOR-MIDS; however, this appears to be an artifact of the COW data. ${ }^{66}$ ) The variable PETROSTATE is generally negative but not statistically significant; this is also consistent with the results of the monadic analysis. ${ }^{67}$ In sum, the results support the hypotheses that oil interacts with the effect of revolutionary governments, and together they generate a strong propensity for states to launch international conflicts.

\section{Robustness Checks and Extensions to Other Natural Resources}

These analyses were subjected to a battery of robustness checks. The following additional control variables were inserted into the analysis: ${ }^{68}$ a lagged dependent variable (to control for rivalries and ongoing disputes); a dummy variable for each year; the COW measure of National Capabilities (CINC); and a dummy for the Iran-Iraq "Tanker Wars." Alternative forms of the dependent variable were used, including: (1) only AGGRESSOR-MIDS in which international force was used (as opposed to including displays and threats of force); (2) all MID onsets, not just

66. Recall that AGGRESSOR-MIDS are identified using the REVISIONIST variable from the COW data set. There are some MIDs in which neither party is coded as revisionist. The results appear to suggest that although revolutionary governments are significantly prone to (nonrevisionist) DEFENDER-MIDS as expected, the other state(s) in these MIDs also tends to be coded as a nonrevisionist party. This leads to the nonsignificant coefficient in Model 6.

67. This analysis was also expanded to include permutations of the three key independent variables for both states in the dyad (for a total of sixteen variables); the results were consistent.

68. Specifically, Model 4 in Table 2 was used as the "base" model, although many of these tests were also performed on other model variants. 
TABLE 3. International disputes by state type-dyadic regression analysis

\begin{tabular}{|c|c|c|c|}
\hline & $\begin{array}{c}\text { Model (6) } \\
\text { AGGRESSOR-MID }\end{array}$ & $\begin{array}{c}\text { Model (7) } \\
\text { DEFENDER-MID }\end{array}$ & $\begin{array}{l}\text { Model (8) } \\
\text { ALL MID }\end{array}$ \\
\hline REVOLUTIONARY GOVERNMENT — STATE A & $\begin{array}{l}0.625 * * \\
(0.145)\end{array}$ & $\begin{array}{c}0.323 * \\
(0.135)\end{array}$ & $\begin{array}{l}0.483 * * \\
(0.106)\end{array}$ \\
\hline PETROSTATE - STATE A & $\begin{array}{r}-0.183 \\
(0.210)\end{array}$ & $\begin{array}{r}-0.089 \\
(0.164)\end{array}$ & $\begin{array}{r}-0.154 \\
(0.139)\end{array}$ \\
\hline PETRO REVOLUTION - STATE A & $\begin{array}{l}0.891 * * \\
(0.276)\end{array}$ & $\begin{array}{c}0.102 \\
(0.272)\end{array}$ & $\begin{array}{l}0.617 * * \\
(0.216)\end{array}$ \\
\hline REVOLUTIONARY GOVERNMENT — STATE B & $\begin{array}{r}-0.021 \\
(0.155)\end{array}$ & $\begin{array}{l}0.799 * * \\
(0.123)\end{array}$ & $\begin{array}{l}0.483^{* *} * \\
(0.106)\end{array}$ \\
\hline PETROSTATE - STATE B & $\begin{array}{r}-0.154 \\
(0.185)\end{array}$ & $\begin{array}{r}-0.168 \\
(0.172)\end{array}$ & $\begin{array}{r}-0.154 \\
(0.139)\end{array}$ \\
\hline PETRO REVOLUTION - STATE B & $\begin{array}{c}0.510 \\
(0.317)\end{array}$ & $\begin{array}{l}0.681 * * \\
(0.237)\end{array}$ & $\begin{array}{l}0.617 * * \\
(0.216)\end{array}$ \\
\hline CIVIL WAR - STATE A & $\begin{array}{c}0.202 \\
(0.143)\end{array}$ & $\begin{array}{l}0.402 * * \\
(0.110)\end{array}$ & $\begin{array}{l}0.334^{* *} \\
(0.099)\end{array}$ \\
\hline CIVIL WAR - STATE B & $\begin{array}{c}0.287 * \\
(0.135)\end{array}$ & $\begin{array}{l}0.333 * * \\
(0.122)\end{array}$ & $\begin{array}{l}0.334^{* *} * \\
(0.099)\end{array}$ \\
\hline DEMOCRACY-DEMOCRACY & $\begin{array}{c}-0.863 * * \\
(0.197)\end{array}$ & $\begin{array}{c}-0.663 * * \\
(0.153)\end{array}$ & $\begin{array}{c}-0.792 * * \\
(0.138)\end{array}$ \\
\hline CONTIGUOUS BORDER & $\begin{array}{l}1.628 * * \\
(0.192)\end{array}$ & $\begin{array}{l}1.512 * * \\
(0.133)\end{array}$ & $\begin{array}{l}1.623 * * \\
(0.112)\end{array}$ \\
\hline FORMER COLONY & $\begin{array}{r}-0.524 \\
(0.279)\end{array}$ & $\begin{array}{c}-0.593 * * \\
(0.226)\end{array}$ & $\begin{array}{c}-0.547 * * \\
(0.202)\end{array}$ \\
\hline COLONIAL CONTIGUITY & $\begin{array}{l}0.698 * * \\
(0.212)\end{array}$ & $\begin{array}{l}0.750 * * \\
(0.180)\end{array}$ & $\begin{array}{l}0.737 * * \\
(0.144)\end{array}$ \\
\hline ALLIANCE S-SCORE & $\begin{array}{r}-0.512 * \\
(0.225)\end{array}$ & $\begin{array}{c}-0.523 * * \\
(0.178)\end{array}$ & $\begin{array}{c}-0.543^{* *} * \\
(0.160)\end{array}$ \\
\hline LOW TRADE DEPENDENCE & $\begin{array}{r}-11.637 \\
(9.793)\end{array}$ & $\begin{array}{r}-12.217 * \\
(5.902)\end{array}$ & $\begin{array}{c}-11.954^{*} \\
(5.922)\end{array}$ \\
\hline SHARED IGOS & $\begin{array}{r}0.016 * \\
(0.007)\end{array}$ & $\begin{array}{c}0.008 \\
(0.004)\end{array}$ & $\begin{array}{l}0.013 * * \\
(0.004)\end{array}$ \\
\hline MAJOR POWER - STATE A & $\begin{array}{r}-0.150 \\
(0.201)\end{array}$ & $\begin{array}{c}0.398 * \\
(0.156)\end{array}$ & $\begin{array}{c}0.173 \\
(0.130)\end{array}$ \\
\hline MAJOR POWER - STATE B & $\begin{array}{c}0.258 \\
(0.182)\end{array}$ & $\begin{array}{c}0.071 \\
(0.156)\end{array}$ & $\begin{array}{c}0.173 \\
(0.130)\end{array}$ \\
\hline$N$ & 71836 & 71836 & 71836 \\
\hline Pseudo- $R^{2}$ & 0.196 & 0.189 & 0.215 \\
\hline
\end{tabular}

Notes: All models use logit regression analysis; rare-events logit used also for robustness. A spline (three knots) of peace years included in the regression but not shown. Standard errors are clustered by directed dyad in parentheses. $\mathrm{IGO}=$ international governmental organization. $* p<.05 ; * * p<.01$.

AGGRESSOR-MIDS. ${ }^{69}$ None of these made a significant change to the size, direction, or statistical significance of the key results. Indeed, the correlation between revolutionary governments in petrostates and conflict is remarkably robust.

69. As an additional robustness check, the analysis was retested using only MIDs with a hostility level of 2 or above on the 5-point scale; the results are consistent. I thank Jessica Weeks for suggesting this check. 
To further probe the robustness of the results, the definition of "revolutionary government" was made broader and then narrower. It was broadened to test whether the transformative domestic policy of a revolutionary government is actually important as an indicator of foreign policy behavior; one could imagine that all governments that have come to power through an irregular transition are similarly inclined to behave aggressively in their foreign policy. The results showed that revolutionary governments are indeed distinct from nonrevolutionary leaders, even if the latter came to power by force. Conversely, if one narrows the definition of "revolutionary government" to include just eleven "unambiguous" cases of revolutionary governments, the effect on MIDs grows even stronger in size and significance. ${ }^{70}$ In addition, the few long-serving revolutionary governments, which had been in power for at least twenty-five years, were excluded after their twentyfourth year to account for the possibility that they were no longer truly revolutionary; this did not significantly affect the results. Also, the definition of revolutionary governments was probed using the AMBIGUOUs coding; again the results were robust. ${ }^{71}$

A series of further robustness tests were conducted. First, all of the tests just described were repeated using country fixed-effects models. Second, all of the stateyears associated with each important country case (for example, Iraq, Iran) were dropped, one country at a time, and the regressions retested. Third, the four variants of the definition of petrostate described above were each substituted for the dichotomous measure PETROSTATE, and the regressions retested. ${ }^{72}$ Fourth, the models were retested when the sample was restricted to the developing countries only (that is, non-OECD). Fifth, all of the independent variables were lagged by one year, to avoid possible endogeneity. In none of these robustness tests did any of the results change materially.

As a final robustness check, the specification of the model was changed from a panel Poisson count model to a logit model, in which the dependent variable is set to 1 if the state engaged in any AGGRESSOR-MIDS in a given year and 0 otherwise. This specification focuses the analysis on the onset of any international dispute rather than on the number of them, to ensure that the results obtained are not driven solely by the observations in which states engaged in multiple AGGRESSOR-MIDS.

70. The eleven "unambiguous" revolutionary leaders/regimes are: Mao (China), Castro (Cuba), Khomeini (Iran), Pol Pot (Cambodia), Ortega (Nicaragua), Banti (Ethiopia), Qadhafi (Libya), Kerekou (Benin), Ngouabi (Congo), Al-Bashir (Sudan), and Ne Win (Myanmar). These regimes are selected based on the frequency with which they have been identified as revolutions by other major scholars (see, for example, Walt 1996; and Huntington 1968). Each of the regimes also had revolutionary societal transformation under at least four of the seven categories identified above.

71. For instance, in one specification, all governments coded as ambiguous were temporarily coded as revolutionary governments; in another specification, they were all temporarily coded as nonrevolutionary governments.

72. Additional analysis also showed that the amount of oil income generated by revolutionary governments may be a statistically significant factor. This issue and its policy implications are the subject of further research. 
Under this specification, none of the results changed materially, again supporting the robustness of the principal findings in Table 2.

The empirical evidence that supports this theory is strongest in the Middle East. It is a simple fact that most petrostates are in the Middle East, and thus the region has the greatest concentration of data points by which this argument can be evaluated. There are fewer data points outside of the Middle East, and it is therefore appropriate to be cautious about the argument's generalizability. However, there are four reasons to believe that the findings are broadly applicable. First, and perhaps most importantly, it is not obvious why one should expect theoretically that the political dynamics of oil should be different in the Middle East than they are elsewhere. In the absence of a well-articulated theory of Middle East exceptionalism, it is reasonable to expect to see similar dynamics in other regions. Second, there are statistical controls in the analysis that ought to isolate a "Middle East effect" for international conflict, to the extent that this exists. Third, the political dynamics described in this article appear to apply to revolutionary governments outside the Middle East, such as in Venezuela, the Congo, and Sudan. For instance, while Venezuela's Chavez has not (yet) initiated a major war, his foreign policy is aggressive and Venezuela has initiated lower-level militarized conflicts, particularly with neighboring Colombia, as expected by the theory. And fourth, this article helps explain the variation within the Middle East. Not all states in the Middle East are conflict prone, and those that are petro-revolutionary are exceptionally so.

Given these findings regarding the impact of oil and revolution on international conflict, it is ordinary to wonder whether other natural resources have a similar effect on the relationship between revolutionary governments and international conflict. Testing this possibility empirically is complex, and a full presentation of analysis results is beyond the scope of this study. Briefly, however, the role of non-oil natural resources was tested using data on the amount of mineral revenue generated by the production of bauxite, copper, iron, lead, nickel, phosphate, tin, zinc, gold, and silver. ${ }^{73}$ Regression analysis suggests that the null hypothesis cannot be rejected-there is no evidence that non-oil natural resources have the same effect as oil on international conflict. ${ }^{74}$ Oil income appears to be genuinely special, potentially because it is more easily controlled and centralized by the state leader: most of the oil industry has been organized into state-owned enterprises, whereas the same is not generally true of other minerals. Also, oil is a strategically more valuable commodity, which might make it more important in international conflicts than other minerals. However, this preliminary "nonresult" should be treated cautiously, as the sample size is small: just seven state-years have both a revolutionary government and a large source of mineral revenues. This topic awaits further investigation.

73. This was done using the World Development Indicator data on "adjusted net savings: mineral depletion."

74. The regression analysis follows the pattern of Model 4 above, with MINERALSTATE and the interaction between MINERALSTATE and REVOLUTIONARY GOVERNMENT added to the existing set of independent variables. 


\section{Does Oil Cause Revolutionary Governments?}

This inquiry started with the observation that petrostates launch more MIDs than nonpetrostates, on average. Revolutionary governments are a key part of the explanation for this fact. The results strongly suggest that the interaction between oil and a revolutionary government has an effect, dramatically raising the state's propensity to aggressively engage in MIDs. Still, it is possible that there is another explanation to the original question. Does a petrostate somehow produce more revolutionary leaders? Could this also help explain the puzzle?

There is little evidence that an oil economy causes the emergence of revolutionary leaders. In the period under investigation, petrostates have been led by revolutionary leaders in slightly more state-years, on average, than nonpetrostates have: 15.8 percent for petrostates, and 15.6 percent for nonpetrostates. ${ }^{75}$ Fully identifying the causes of revolutionary governments would require a causal model, which is far beyond the scope of this project. This study treats the causes of revolutions as exogenous. Nonetheless, a preliminary investigation of the correlational relationship between petrostates and revolutions is possible. The data set on revolutionary governments has been used thus far as an independent variable in this article, but it can also be used as a dependent variable. Logit regression analysis can be used to examine the correlates of revolutionary governments, using many of the same correlates that have been used throughout this empirical investigation. Table 4 below shows the results from this preliminary model of the relationship between petrostates and revolutionary governments.

The results suggest that petrostates are not strongly correlated with revolutionary governments, throwing any hypothesized causal relationship into doubt. Model 9 is a basic bivariate regression, using only the PETROSTATE variable. This simple regression shows no correlation between petrostates and revolutionary governments. In Model 10, the state's GDP per capita, population, and Polity score are added as control variables, as well as the COLD WAR variable, regional dummy variables, and the Muslim percentage of the population. Again, the coefficient for PETROSTATE is close to zero and statistically insignificant. The results indicate that poorer, more populous, and more autocratic countries are more likely to experience revolutionary governments. Notably, the coefficient for the Middle East region (not shown in Table 4) is also positive and strongly significant. Model 11 is similar but includes fixed effects; again, the results fail to reject the null hypothesis. While these results do not represent a comprehensive causal model of the incidence of revolutionary governments, they suggest that there is no correlational or causal relationship between petrostates and revolutionary governments.

75. These figures are for developing countries only; Organization for Economic Cooperation and Development (OECD) states are excluded. However, OECD states are included in the regression analyses. Clearly, these numbers represent cross-national averages: some states such as Cuba and Libya have been led by revolutionary leaders for as much as 80 percent of the years under investigation, while others have not seen any revolutionary leaders. 
TABLE 4. Correlates of revolutionary governments

\begin{tabular}{lccc}
\hline & $\begin{array}{c}\text { Model (9) } \\
\text { Bivariate }\end{array}$ & $\begin{array}{c}\text { Model (10) } \\
\text { Basic }\end{array}$ & $\begin{array}{c}\text { Model (11) } \\
\text { FE }\end{array}$ \\
\hline PETROSTATE & 0.208 & -0.286 & -0.714 \\
& $(0.223)$ & $(0.339)$ & $(0.396)$ \\
GDP/CAP, log & & $-0.593^{* *}$ & $-1.106^{* *}$ \\
& & $(0.116)$ & $(0.149)$ \\
POPULATION, log & $0.983^{* *}$ & $3.066^{* *}$ \\
& & $(0.073)$ & $(0.268)$ \\
POLITY IV & & $-0.230^{* *}$ & $-0.241^{* *}$ \\
& & $(0.014)$ & $(0.016)$ \\
COLDWAR & & 0.169 & $1.251^{* *}$ \\
& & $(0.158)$ & $(0.215)$ \\
MUSLIM, \%POPULATION & & 0.843 & \\
Fixed effects & & $(0.702)$ & Yes \\
$N$ & No & 6246 & 2551 \\
Log-likelihood & 6838 & -1231 & -897 \\
\hline
\end{tabular}

Notes: All models use logit regression analysis for time-series panel data. For each variable, standard errors are given in parentheses. Regional dummies included but not shown, except in Model 9. FE = fixed effects. * $p<.05$; $* * p<.01$.

Thus this prima facie investigation into the relationship of oil and revolutionary governments suggests that oil probably does not cause revolutions. Rather it is the interaction between a revolutionary government and significant oil income that is the key driver in explaining why petrostates launch so many militarized interstate disputes.

\section{Conclusion}

This article sheds new light on the relationship between oil and international conflict. Petro-revolutionary governments constitute a special threat to international peace and security. The evidence reveals that petrostates led by revolutionary leaders are dramatically more aggressive and launch more MIDs than other kinds of states, even compared to nonpetrostates that are led by revolutionary leaders. The interaction of oil and revolution often leads to a state with an unrestrained, warlike government capable of harnessing a significant portion of the state's resources toward international conflict. In short, the combination of oil and revolutionary governments is explosive.

The implications for the global political economy are significant. Petrostates were involved in 22 percent of all MIDs since 1970, even though they are just thirty-one states and a small fraction of the world's population. The international trade of oil injects vast amounts of money into political systems that are ill-suited to receive it, with significant consequences for the centralization of political power 
and the buildup of military capability in oil-exporting states. These facts raise a host of political, economic, and moral questions about the world's continued dependence on petroleum as a primary source of energy in advanced economies. Indeed, given that oil income plays a causal role in backing aggressive foreign policy, policymakers may find it desirable to minimize the flow of such income into states led by aggressive leaders.

These findings are especially significant in light of Middle East politics. Observing the correlation between oil and international conflict, one might be tempted to believe that this is because much of the world's oil is found in the Middle East, and the Middle East is a violent and conflict-prone region. On that view, the correlation might be spurious. However, this study shows that when the analysis controls and adjusts for regional effects, the effect of petro-revolutionary governments remains strong. That is, even relative to other Middle East states, the petrorevolutionary governments in states such as Iraq, Libya, and Iran are especially prone to aggressively engage in MIDs. Moreover, the toxic interaction between oil income and revolutionary governments can be seen in the behavior of states outside of the Middle East, such as Venezuela. On the whole, the evidence suggests that oil contributes significantly to the violence in the Middle East.

Perhaps surprisingly, the evidence shows that petrostates with nonrevolutionary governments have a propensity for AGGRESSOR-MIDS equal to or somewhat lower than comparable nonpetrostates. This is consistent with the theoretical framework tested here. This finding is even more striking because the opposite trend holds overall. The implication is that the overall above-average rate of MIDs is driven largely by the small subset of revolutionary governments in petrostates, which have an extremely high propensity for international conflict.

TABLE A1. List of petrostates, 1945-2001

\begin{tabular}{lll}
\hline State & Period as petrostate & Petro-revolutionary period \\
\hline Qatar & $1971-2001$ & \\
UAE & $1971-2001$ & \\
Kuwait & $1961-2001$ & \\
Bahrain & $1971-2001^{1}$ & \\
Saudi & $1945-2001$ & \\
Oman & $1971-2001$ & $1969-2001$ \\
Libya & $1961-2001$ & $1979-1996$ \\
Iran & $1945-2001$ & $1958-2001$ \\
Iraq & $1945-2001$ & 2 \\
Syria & $1974-1981,1989-2001$ & $1966-1977$ \\
Algeria & $1962-2001$ & $1991-1999$ \\
Yemen & $1990-2001$ & \\
Russia & $1991-2001^{3}$ & \\
Turkmenistan & $1991-2001^{3}$ &
\end{tabular}


TABLE A1. Continued

State

Petro-revolutionary period

Kazakhstan
Azerbaijan
Indonesia
Venezuela
Ecuador
Trinidad and Tobago
Nigeria
Angola
Gabon
Equatorial Guinea
Congo
Sudan
Cameroon
Brunei
Egypt
Malaysia
Norway
Mexico
Tunisia

$$
\begin{aligned}
& 1996-2001^{3} \\
& 1991-2001^{3} \\
& 1949-1990^{4} \\
& 1945-2001 \\
& 1973-2001 \\
& 1962-2001 \\
& 1961-2001 \\
& 1975-2001 \\
& 1967-2001 \\
& 1993-2001 \\
& 1973-2001 \\
& 2000-2001 \\
& 1980-1998 \\
& 1984-2001^{1} \\
& 1977-1985 \\
& 1979-1990^{4} \\
& 1980-2001^{4} \\
& 1980-1983 \\
& 1974-1985^{4}
\end{aligned}
$$

1999-2001

1973-1976

$2000-2001^{2}$

$1977-1980^{2,5}$

Notes: The time period of analysis is 1945-2001.

1. State excluded from analysis due to missing data.

2. Revolutionary periods when the state is not classified as a petrostate are not listed (for example, Syria 1963-69).

3. The USSR is not included in this analysis for reasons of data availability and consistency.

4. The state did not qualify as a petrostate for all years in this period.

5. Period of revolutionary leadership that is classified as ambiguous.

\section{References}

Barbieri, Katherine. 2005. The Liberal Illusion: Does Trade Promote Peace? Ann Arbor: University of Michigan Press.

Beck, Nathaniel, Jonathan N. Katz, and Richard Tucker. 1998. Taking Time Seriously: Time-SeriesCross-Section Analysis with a Binary Dependent Variable. American Journal of Political Science 42 (4):1260-88.

Blainey, Geoffrey. 1988. The Causes of War. 3d ed. New York: Free Press.

Bueno de Mesquita, Bruce, Alastair Smith, Randolph M. Siverson, and James D. Morrow. 2003. The Logic of Political Survival. Cambridge, Mass.: MIT Press.

Chiozza, Giacomo, and Henk E. Goemans. 2004. Avoiding Diversionary Targets. Journal of Peace Research 41 (4):423-43.

Collier, Paul, and Anke Hoeffler. 2004. Greed and Grievance in Civil War. Oxford Economic Papers 56 (4):563-95.

Dahl, Robert A. 1961. Who Governs? Democracy and Power in an American City. New Haven, Conn.: Yale University Press.

Dunning, Thad. 2008. Crude Democracy: Natural Resource Wealth and Political Regimes. Cambridge: Cambridge University Press.

Enterline, Andrew J. 1998. Regime Changes and Interstate Conflict, 1816-1992. Political Research Quarterly 51 (2):385-409. 
Fearon, James D. 1994. Domestic Political Audiences and the Escalation of International Disputes. American Political Science Review 88 (3):577-92.

. 1995. Rationalist Explanations for War. International Organization 49 (3):379-414.

Fearon, James D., and David D. Laitin. 2003. Ethnicity, Insurgency, and Civil War. American Political Science Review 97 (1):75-90.

Filson, Darren, and Suzanne Werner. 2004. Bargaining and Fighting: The Impact of Regime Type on War Onset, Duration, and Outcomes. American Journal of Political Science 48 (2):296-313.

Gartzke, Erik. 2007. The Capitalist Peace. American Journal of Political Science 51 (1):166-91.

Gleditsch, Kristian Skrede, Idean Salehyan, and Kenneth Schultz. 2008. Fighting at Home, Fighting Abroad: How Civil Wars Lead to International Disputes. Journal of Conflict Resolution 52 (4):479-506.

Gurr, Ted Robert. 1988. War, Revolution, and the Growth of the Coercive State. Comparative Political Studies 21 (1):45-65.

Homer-Dixon, Thomas F. 1991. On the Threshold: Environmental Changes as Causes of Acute Conflict. International Security 16 (2):76-116.

Huntington, Samuel P. 1968. Political Order in Changing Societies. New Haven, Conn.: Yale University Press.

- 1996. The Clash of Civilizations and the Remaking of World Order. New York: Simon and Schuster.

Jones, Daniel M., Stuart A. Bremer, and J. David Singer. 1996. Militarized Interstate Disputes, 18161992: Rationale, Coding, Coding Rules, and Empirical Patterns. Conflict Management and Peace Science 15 (2):163-213.

Karl, Terry Lynn. 1997. The Paradox of Plenty: Oil Booms and Petro-States. Berkeley: University of California.

Keohane, Robert O., and Joseph S. Nye. 1977. Power and Independence. Boston: Little Brown.

Klare, Michael T. 2002. Resource Wars: The New Landscape of Global Conflict. New York: Holt.

- 2004. Blood and Oil: The Dangers and Consequences of America's Growing Dependency on Imported Petroleum. New York: Metropolitan.

- 2008. Rising Powers, Shrinking Planet: The New Geopolitics of Energy. New York: Metropolitan Books.

Kydd, Andrew. 2000. Trust, Reassurance, and Cooperation. International Organization 54 (2):325-57. Lai, Brian, and Dan Slater. 2006. Institutions of the Offensive: Domestic Sources of Dispute Initiation in Authoritarian Regimes, 1950-1992. American Journal of Political Science 50 (1):113-26.

Levy, Jack S. 1988. Domestic Politics and War. Journal of Interdisciplinary History 18 (4):653-73.

Lo, Nigel, Barry Hashimoto, and Dan Reiter. 2008. Ensuring Peace: Foreign-Imposed Regime Change and Postwar Peace Duration, 1914-2001. International Organization 62 (4):717-36.

Mansfield, Edward D., and Jack Snyder. 2005. Electing to Fight: Why Emerging Democracies Go to War. Cambridge, Mass.: MIT Press.

Maoz, Zeev. 1989. Joining the Club of Nations: Political Development and International Conflict, 18161976. International Studies Quarterly 33 (2):199-231.

- 1996. Domestic Sources of Global Change. Ann Arbor: University of Michigan Press.

Maoz, Zeev, and Bruce Russett. 1993. Normative and Structural Causes of Democratic Peace. American Political Science Review 87 (3):624-38.

Marshall, Monty G., and Keith Jaggers. 2010. Polity IV Project: Political Regime Characteristics and Transitions, 1800-2008. Available at 〈http://www.systemicpeace.org/polity/polity4.htm $\rangle$. Accessed 22 June 2010.

Martin, Lisa L. 1993. Coercive Cooperation: Explaining Multilateral Economic Sanctions. Princeton, N.J.: Princeton University Press.

Mearsheimer, John J. 1990. Back to the Future: Instability in Europe After the Cold War. International Security 15 (1):5-56.

Morgenthau, Hans J. 2005. Politics Among Nations. 7th ed. Revised by Kenneth Thompson and David Clinton. New York: McGraw-Hill.

Morrison, Kevin M. 2009. Oil, Nontax Revenue, and the Redistributional Foundations of Regime Stability. International Organization 63 (1):107-38. 
O’Neal, John R., and Bruce Russett. 2001. Triangulating Peace: Democracy, Interdependence, and International Organizations. New York: Norton.

Organski, A. F. K., and Jacek Kugler. 1980. The War Ledger. Chicago: University of Chicago Press.

Powell, Robert. 1999. In the Shadow of Power: States and Strategies in International Politics. Princeton, N.J.: University Press.

Putnam, Robert D. 1988. Diplomacy and Domestic Politics: The Logic of Two-Level Games. International Organization 42 (3):427-60.

Ramsay, Kristopher W. 2006. The Price of Oil and Democracy. Working paper. Princeton, N.J.: Princeton University. Available at 〈http://cpe.wustl.edu/seminars/ramsay.pdf). Accessed 22 June 2010.

Ross, Michael. 2001. Does Oil Hinder Democracy? World Politics 53 (3):325-61.

. 2004. What Do We Know About Natural Resources and Civil War? Journal of Peace Research 41 (3):337-56.

- 2006. A Closer Look at Oil, Diamonds, and Civil War. Annual Review of Political Science 9:265-300.

Russett, Bruce. 1981. Security and the Resources Scramble: Will 1984 Be Like 1914? International Affairs 58 (1):42-58.

Skocpol, Theda. 1988. Social Revolutions and Mass Military Mobilization. Revolution: Critical Concepts in Political Science 40 (2):147-68.

Smith, Benjamin. 2004. Oil Wealth and Regime Survival in the Developing World, 1960-1999. American Journal of Political Science 48 (2):232-46.

Snyder, Robert S. 1999. The U.S. and Third World Revolutionary States: Understanding the Breakdown in Relations. International Studies Quarterly 43 (2):265-90.

Tomz, Michael. 2007. Domestic Audience Costs in International Relations: An Experimental Approach. International Organization 61 (4):821-40.

Victor, David G. 2007. What Resource Wars? The National Interest Online. Available at 〈http:// www.nationalinterest.org/Article.aspx?id=16020). Accessed 22 June 2010.

Walt, Stephen M. 1996. Revolution and War. Ithaca, N.Y.: Cornell University Press.

Westing, Arthur H. 1986. Global Resources and International Conflict: Environmental Factors in Strategic Policy and Action. Oxford, England: Oxford University Press.

Wooldridge, Jeffrey M. 2002. Econometric Analysis of Cross Section and Panel Data. Cambridge, Mass.: MIT Press.

World Bank. Various years. World Development Indicators. Washington, D.C.: World Bank. 